\title{
Qualitative Study of Wives of Husbands with Autism Spectrum Disorder: Subjective Experience of Wives from Marriage to Marital Crisis
}

\author{
Naoko Deguchi' ${ }^{1}$ Takashi Asakura ${ }^{2}$ \\ ${ }^{1}$ The United Graduate School of Education, Tokyo Gakugei University, Tokyo, Japan \\ ${ }^{2}$ Laboratory of Health and Social Behavior, Tokyo Gakugei University, Tokyo, Japan \\ Email: r168004y@st.u-gakugei.ac.jp
}

How to cite this paper: Deguchi, N., \& Asakura, T. (2018). Qualitative Study of Wives of Husbands with Autism Spectrum Disorder: Subjective Experience of Wives from Marriage to Marital Crisis. Psychology, 9, 14-33.

https://doi.org/10.4236/psych.2018.91002

Received: November 21, 2017

Accepted: January 8, 2018

Published: January 11, 2018

Copyright $\odot 2018$ by authors and Scientific Research Publishing Inc. This work is licensed under the Creative Commons Attribution International License (CC BY 4.0).

http://creativecommons.org/licenses/by/4.0/

\begin{abstract}
Despite increasing recognition of the involvement of adults with autism spectrum disorder (ASD) in intimate relationships, little is known about the dynamics of marriages where one partner has ASD. This study aimed to clarify the subjective experiences of wives of husbands with ASD from marriage to marital crisis. Semi-structured interviews were conducted with 15 women married to men with ASD in Japan, in 2016-17. The analysis conducted in this study was based on a modified version of the grounded theory approach. Our investigation revealed how the wives of ASD husbands respond to a crisis after their marriage. The findings describe a process beginning with wives perceiving their husbands as attractive before marriage and then progressing to feeling discomfort with their husbands and struggling with loneliness after marriage. Experiences with social exclusion/inclusion affected this progression. The wives' repeated discomfort with their husbands and struggles with loneliness eventually led to a major crisis. Finally, the work discusses how these findings may contribute to improving the lives of women with partners with ASD and advances the family stress model.
\end{abstract}

\section{Keywords}

Autism Spectrum Disorder, Marital Crisis, Spouses, Subjective Experiences, Qualitative Study

\section{Introduction}

Major behavioral characteristics of autism spectrum disorder (ASD) include 
persistent deficits in social communication, social interactions, social-emotional reciprocity, and communicative behavior (American Psychiatric Association, 2013). Hitherto, such people were thought to be awkward in interpersonal relationships, or it was assumed that ASD adults would rarely get married (Seltzer, Shattuck, Abbeduto, \& Greenberg, 2004). Accordingly, marriage in such individuals has seldom been explored (Engström, Ekström, \& Emilsson, 2003). Despite having characteristics that make them poor at handling interpersonal relationships and communication, it is now acknowledged that increasing numbers of high-functioning individuals with ASD are in fact establishing intimate relationships (Strunz et al., 2017). This emerging social phenomenon has led to new research interest in high-functioning ASD; we address this topic in the present study.

In recent years, many high-functioning individuals with ASD have engaged in sex with men and women (Byers, Nichols, \& Voyer, 2013; Hellemans, Colson, Verbraeken, Vermeiren, \& Deboutte, 2007) and developed romantic relationships (Strunz et al., 2017); the proportion of them who marry has been reported as $10 \%$ (Yukawa et al., 2013) to 16\% (Tani et al., 2012). There are increasing opportunities for ASD individuals to get married; that means there are challenges for ASD individuals in maintaining long-term relationships and marrying (Howlin, Mawhood, \& Rutter, 2000; Orsmond, Krauss, \& Seltzer, 2004; Renty \& Roeyers, 2007). However, since interaction, communication, and commitment are essential for such intimate interpersonal relationships (Le, Dove, Agnew, Korn, \& Mutso, 2010) the characteristics of ASD may be disadvantageous for these relationships. Commitment signifies a broad, long-term orientation toward a relationship (Rusbult \& Buunk, 1993), but ASD individuals have particular difficulties of keeping long-term relationships with their partners.

Many high-functioning ASD individuals who have no problem with language development often have difficulty in social skills and communication; that is even true in cases where they have a very high IQ. In such situations, there can be a large impact on romantic relationships and sexual relations (Howlin, Mawhood, \& Rutter, 2000; Orsmond, Krauss, \& Seltzer, 2004).

There has been an increase in the number of books about the difficulties a wife with an ASD husband has to face (Aston, 2003). There is quantitative research on low marriage satisfaction. Renty et al. (2007) examined the predictive value of marital adaptation in adult men with ASD and their spouses; the authors found that informal support was a strong predictor of adaptation among the spouses. One study found that the marital satisfaction of a partner with ASD was significantly lower than that of a partner without ASD (Lau \& Peterson, 2011). The marital satisfaction of a wife without ASD whose husband had the condition was significantly lower than a couple where both partners had ASD and a couple where neither partner had ASD (Kanroji, 2012).

Little research has been conducted on qualitative marital experience in the case of individuals with disabilities. It has been found that where one of the 
partners has dyslexia, there may be communication problems as well (Alexander-Passe, 2015). However, no studies have qualitatively clarified the process of marriage in the case of a wife with an ASD husband.

There are a couple of reasons for the wife having attracted greater attention than the husband. First, men are diagnosed as having ASD more than women. Accordingly, there are more wives who have such individuals as their spouse. Second, normative consciousness, such as the sexual role division of labor and strong emotional ties (Emiko, 1989), which are characteristic of modern families, leads to endurance even if the wife has difficulties. Thus, in Japan, the problems for the wife are greater.

As yet, there is insufficient understanding of marital difficulties where the husband has ASD and the wife does not. Regardless of the presence or absence of a disability, intimate relationships undergo change. Sometimes, a relationship based purely on attraction is doomed to failure (Felmlee, 1995). However, by the presence of ASD, intimate relationships may superficially appear to be subjected to similar kinds of phenomena; the characteristics of ASD individuals may affect their relationships in different ways. For example, in the case of having an ASD husband, the wife may have to withstand certain difficulties with regard to her husband's behavior, and such difficulties may have a direct impact on a daily marriage life.

A family stress model may be used to examine marital stress in the case of ASD individuals. Based on previous stress research, Hill developed the ABCX Formula, which is now better known as the ABCX Model (Hill, 1958). The ABCX Formula forms the basis for most family stress models. The family stress model provides an effective framework for crisis or adaptation in case of families facing stressors.

However, family stress theory has its limitations. This theory focuses just on major life events. As a result, family members are subject to survey only after a particular life event has taken place. Thus, the theory cannot be applied to changes before a family life event has occurred. The beginning of a marriage is not a crisis situation. Marriage starts following the development of a relationship between two people, and any changes that take place in that relationship could create stress.

Recently, the effect of daily problems has drawn attention. One study has found that daily stress has a stronger impact on family relationships than critical life events (Bodenmann, Ledermann, \& Bradbury, 2007). Toward understanding the underlying factors related to crises in married life, future research needs to examine daily stress that takes place before a crisis life event occurs.

It is also necessary to integrate family stress theory with couple stress theory (Lavee, 2013). The marital crisis model becomes reinforced when it integrates the process of couples developing their relationships with family stress theory. The findings that arise from this combination could contribute to the development of conventional family stress theory. 
The purpose of this study was to clarify the subjective experiences of wives of husbands with ASD from marriage to marital crisis.

\section{Methods}

\subsection{Design}

The analysis conducted in this study was based on a modified version of the grounded theory approach (M-GTA) (Kinoshita, 2003); that was developed by adopting the theoretical and content properties of the grounded theory approach (GTA) (Glaser \& Strauss, 1967). The M-GTA is different from the classic GTA in two ways. First, with M-GTA, raw data are analyzed according to an analytic theme based on the analytic target's viewpoint. The analytic and analytic participants are decided on the basis of the research question chosen. Therefore, a clearly stated research question is of great importance when setting the analytic theme and target in an M-GTA analysis. Second, M-GTA is different from the GTA in the strict coding procedure. The raw data are not broken down into fragments for coding; that makes it possible to determine the meaning of any content at the root of the raw data. In the present study, the coding procedure was guided by the M-GTA, which provides explicit instructions in coding. We believed it would be appropriate to supply full details of the statements made by the wives. We did so since we thought it would be beneficial in explaining the relationship between husband and wife.

\subsection{Participants}

We recruited our participants from two self-help groups for ASD wives and one educational institution based in the Greater Tokyo Area. The Greater Tokyo Area is the most populous metropolitan area in Japan. To recruit wives with the greatest possible range of experiences, we asked a representative of each group to select maximum sampling from the viewpoint of age, marriage years, marital status, and husband's diagnosis of ASD. Because the Greater Tokyo Area is an urban area with self-help groups for ASD wives, wives with many societal relations could be sampled.

The potential participants received a request from the group representative, who explained to them the purpose of the study and asked if they wished to participate. Out of 17 individuals who received the request to participate, 15 contacted the researchers, indicating their willingness to take part in the study; they were subsequently interviewed. One of the two did not contact us was in a poor physical condition and did not wish to undertake an interview. The other person was then residing in a somewhat distant place, which would have made an interview impractical.

\subsection{Data Collection}

The interviews were conducted from July 2016 to March 2017. One author conducted a semi-structured interview, lasting about 40 minutes to 2 hours per person. 
The interview was conducted on a one-to-one basis. To guarantee the privacy and comfort of the participants, the location was a quiet, private room, such as a public lounge or the participant's home; that was in accordance with the participant's wishes. After receiving the participant's permission, the interview was recorded on an IC recorder, and one of the authors transcribed it verbatim.

\subsection{Interview Guide}

The guide we made for our interviews was as follows: (1) impressions the future husband made on their partner prior to marriage; (2) circumstances attending the decision to marry; (3) how the wife's feelings had changed with respect to the husband following marriage; (4) difficulties that the wife had encountered in life with her husband; and (5) how the wife had felt herself change during her life with her husband. To obtain an accurate narrative from the participants, we addressed the topics in chronological order. Furthermore, to understand the participants and to draw out the narrative, we conducted pilot interviews with each representative of the two self-help groups, i.e., one with ASD wives and one with an educational institution.

\subsection{Analysis Strategy}

In this study, the theme of our analysis was as follows: the course of marriage to the point of marriage crisis among wives married to husbands with ASD or suspected of having ASD. Our participants were thus wives of husbands with ASD or suspected of having ASD. We conducted our M-GTA analysis as follows: (1) We used one worksheet to generate one concept. First, we selected interview data related to the analytic theme and recorded them in the example column. Next, we detailed the reasons for us choosing the data and how we interpreted the content of the examples. (2) We used comparative analysis to examine similar or converse examples. (3) We aimed to determine a common meaning among many examples. With coding, we described the concept definition and the concept name in few words. (4) We generated multiple concepts. We examined the intercept relationships to clarify their directionality and create a category that subsumed those concepts. (5) We developed a schematized diagram of the relationship among concepts and categories; we formulated the core category. (6) We evaluated the theoretical saturation whereby no additional concepts could be generated and when available concepts and categories were deemed sufficient to explain the phenomena described by the analytic theme.

\subsection{Ethical Considerations}

The study participants provided their written informed consent after we explained the purpose and methods of the study. Participants were told that they were free to renounce their cooperation at any point during the study. We informed participants of privacy protection, our recording of interviews, and the publication of research results. This study was conducted with the approval of 
the Ethics Committee of Tokyo Gakugei University (authorization number 186).

\section{Results}

\subsection{Participant Characteristics}

The characteristics of the 15 participants appear in Table 1.

\subsection{Process from Marriage to Marital Crisis}

We extracted 53 concepts, 19 categories, and six core categories. We examined the process from marriage to marital crisis based on core categories and categories (Figure 1). We use symbols to identify the content as follows: [core category]; <category name>; "participant quotes". The details are as follows.

First, the wives felt [attraction to the husband], and they got married without being aware that the husband had ASD. Second, the wives began to feel [discomfort with the husband] in their married life. Third, the wives started to [struggle with a sense of loneliness] through the repeated feelings of discomfort

Table 1. Participant characteristics $(\mathrm{N}=15)$.

\begin{tabular}{|c|c|c|c|}
\hline \multicolumn{2}{|c|}{ Characteristic } & $\mathrm{N}$ & $\%$ \\
\hline \multicolumn{4}{|l|}{ Age } \\
\hline \multicolumn{4}{|l|}{ Wife } \\
\hline & $40-49$ & 3 & 20.0 \\
\hline & $50-59$ & 9 & 60.0 \\
\hline & $60-69$ & 3 & 20.0 \\
\hline \multicolumn{4}{|c|}{ Husband } \\
\hline & $40-49$ & 3 & 20.0 \\
\hline & $50-59$ & 7 & 46.7 \\
\hline & $60-69$ & 5 & 33.3 \\
\hline \multicolumn{4}{|l|}{ Marriage years } \\
\hline & $1-9$ & 1 & 6.7 \\
\hline & $10-19$ & 2 & 13.3 \\
\hline & $20-29$ & 8 & 53.3 \\
\hline & $30-39$ & 3 & 20.0 \\
\hline & $40-49$ & 1 & 6.7 \\
\hline \multicolumn{4}{|l|}{ Marital status } \\
\hline & Living together & 13 & 86.7 \\
\hline & Separated & 1 & 6.7 \\
\hline & Divorced & 1 & 6.7 \\
\hline \multicolumn{4}{|c|}{ Husband's diagnosis of autism spectrum disorder } \\
\hline & Diagnosed & 6 & 40.0 \\
\hline & Undiagnosed & 9 & 60.0 \\
\hline
\end{tabular}




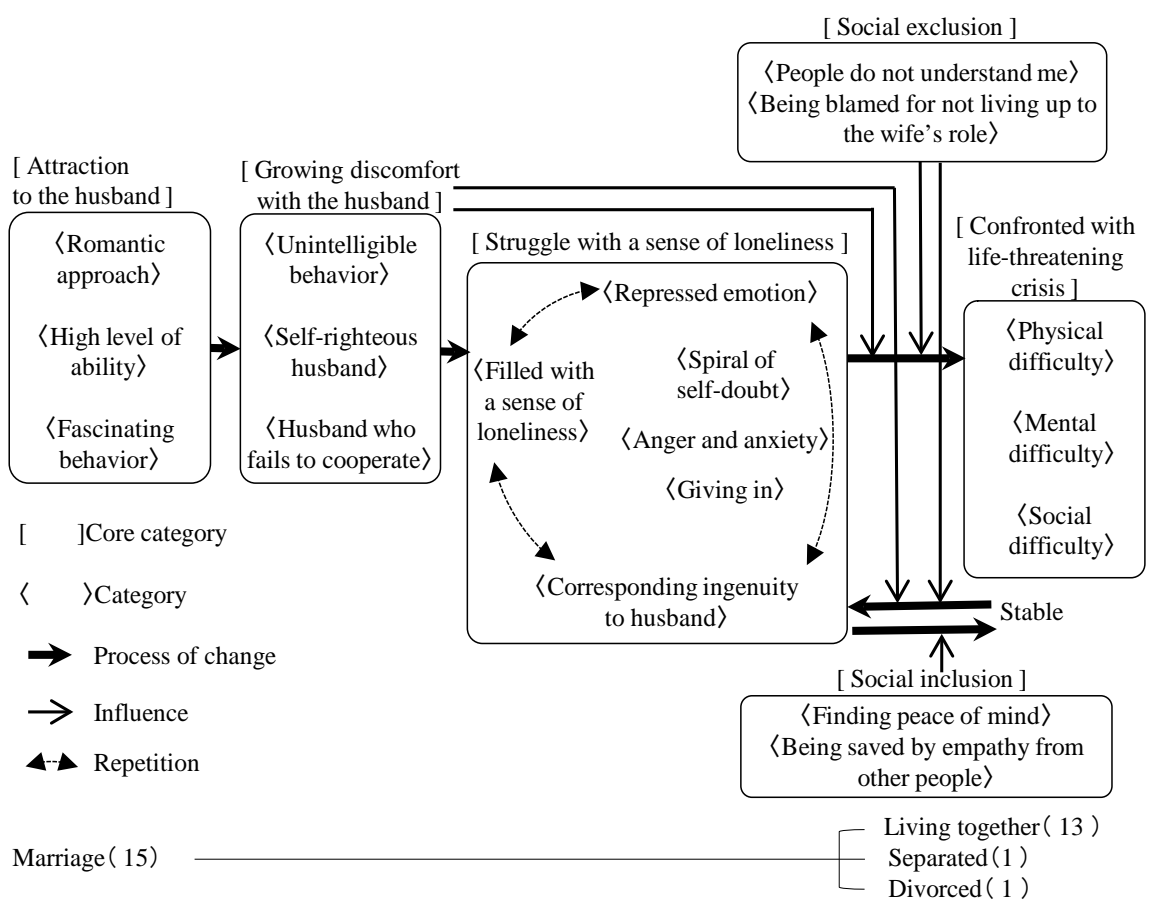

Figure 1. Process from marriage to marital crisis.

on a daily basis. The wives were affected by [social exclusion] or [social inclusion] during that process. Finally, after the [struggle with a sense of loneliness] was prolonged, that led to their [confrontation with a life-threatening crisis]. The following sections address the six core categories.

\subsection{Attraction to the Husband}

This core category covered the wife's attraction to the husband from first meeting to marriage. The categories, concepts, and definitions here appear in Table 2. The wives described various attractions of their husbands, and they can be broadly classified roughly into three areas: romantic approach, high level of ability, and Fascinating behavior. At the time of their marriage, the wives were unaware that their husbands had the characteristics of ASD. The wives recognized the husbands' charms and characteristics that were different to their own. The attraction to the husband was strengthened by the characteristics of ASD.

\subsubsection{Romantic Approach}

According to several wives, their husbands' approach was a dramatic one that they had never experienced before. The wives indicated that this approach had been a decisive factor.

"He said 'Your feelings are irrelevant. I told you I like you.' It was almost like the kind of thing you see in TV dramas. In books, female characters do not forget how a man first approached them and how they somehow feel tied to the man. I thought the same was true for me. I thought that he was a strange person, but being treated as a woman in that way was an unexpected experience." (B) 
Table 2. Attraction to the husband.

\begin{tabular}{|c|c|c|}
\hline Category & Concept & Definitions \\
\hline $\begin{array}{l}\text { Romantic } \\
\text { approach }\end{array}$ & Dramatic behavior & A dramatic approach as in the movies \\
\hline \multirow{3}{*}{$\begin{array}{l}\text { High level } \\
\text { of ability }\end{array}$} & Abundant knowledge & $\begin{array}{l}\text { Concern and respect for abundant specific knowledge } \\
\text { that cannot be denied by others }\end{array}$ \\
\hline & High ability & Good impression of the husband's high ability level \\
\hline & Common hobby & The wife likes her husband through sharing a hobby \\
\hline \multirow{5}{*}{$\begin{array}{l}\text { Fascinating } \\
\text { behavior }\end{array}$} & Purity & $\begin{array}{l}\text { The wife feel attracted to the purity and honesty which } \\
\text { is clear compared with other people of the same age }\end{array}$ \\
\hline & Kindness & $\begin{array}{l}\text { The wife feels attracted to the husband's kindness and } \\
\text { acceptance of her }\end{array}$ \\
\hline & Calmness & The wife wishes a gentle husband without assertiveness \\
\hline & Interesting & The wife likes her husband's exceptional ideas \\
\hline & Aggression & $\begin{array}{l}\text { The wife likes an active husband who can take clear } \\
\text { actions in line with traditional Japanese culture }\end{array}$ \\
\hline
\end{tabular}

\subsubsection{High Level of Ability}

The wives spoke of their husbands' abundant knowledge and how they had respect for his ability. Some wives shared a hobby with their husband, and they felt attracted to the husband because his skills were better than their own.

"His hobby was music. He knew music very well, and I also liked his favorite kinds of music. Because he knew music, it was fun to talk to him. I liked him, and we got married." $(\mathrm{H})$

\subsubsection{Fascinating Behavior}

The wives related certain behavioral features as being attractions of the husband, such as purity, being interesting, kindness, calmness, and assertiveness.

"I felt that he was pure. He had a kind of purity, but he didn't expect anything back in return." (B)

"He agrees with all I say and comments that it is nice. I liked his gentle personality." (E)

\subsection{Growing Discomfort with the Husband}

The categories, concepts, and definitions here appear in Table 3. This can be classified into three areas: unintelligible behavior, self-righteous husband, and husband who fails to cooperate. This discomfort was experienced repeatedly in everyday life; even if one area of discomfort became resolved, a characteristic feature was other areas of discomfort appeared. Unintelligible behavior was a common feature among all the wives and caused confusion. The unpredictability of the husband's behavior when living together led to the wives being unable to predict their futures.

One wife talked about her self-righteous husband and how he had "dramatic 
Table 3. Growing discomfort with the husband.

\begin{tabular}{|c|c|c|}
\hline Category & Concept & Definitions \\
\hline \multirow{3}{*}{$\begin{array}{l}\text { Unintelligible } \\
\text { behavior }\end{array}$} & $\begin{array}{l}\text { Cannot understand the } \\
\text { husband's intention }\end{array}$ & $\begin{array}{l}\text { The wife is confused because her husband's } \\
\text { intention is not understood }\end{array}$ \\
\hline & $\begin{array}{l}\text { Behavior inappropriate } \\
\text { to the place }\end{array}$ & $\begin{array}{l}\text { The wife feels that her husband's behavior does } \\
\text { not match the circumstances }\end{array}$ \\
\hline & Unexpected reaction & $\begin{array}{l}\text { The husband does not understand what the wife } \\
\text { wants and they do not do anything together }\end{array}$ \\
\hline \multirow{2}{*}{$\begin{array}{l}\text { Self-righteous } \\
\text { husband }\end{array}$} & Soon gets angry & $\begin{array}{l}\text { When the wife goes against the husband's wishes } \\
\text { a little, he gets angry }\end{array}$ \\
\hline & Disagreeing with wife & $\begin{array}{l}\text { The husband decides by himself what to do } \\
\text { with the family }\end{array}$ \\
\hline \multirow{2}{*}{$\begin{array}{l}\text { Husband who fails } \\
\text { to cooperate }\end{array}$} & $\begin{array}{l}\text { Determined not to be } \\
\text { consulted }\end{array}$ & $\begin{array}{l}\text { The wife wants to discuss and consult a problem, } \\
\text { but her husband does not offer an opinion and } \\
\text { will not consult }\end{array}$ \\
\hline & $\begin{array}{l}\text { Forced to decide } \\
\text { everything alone }\end{array}$ & $\begin{array}{l}\text { The husband does not commit to the family, so } \\
\text { the wife must decide everything for her family }\end{array}$ \\
\hline
\end{tabular}

behavior" was "interesting" and showed "assertiveness." Those were aspects of attraction to the husband before the marriage.

Changes that occurred with respect to attraction included the wife considering what had been a humorous behavior regarding the husband becoming odd in behavior, and the wife finding the aggression of the husband becoming increasingly unattractive. If the husband did not listen to the wife, she gradually became unable to talk to him at home, and she began to endure a sense of loneliness. However, there was also a wife who talked about her husband who fails to cooperate did have kindness and calmness, which were the husband's areas of attraction before the marriage. The attraction that the wife felt as kindness and calmness changed into discomfort in that the husband would not commit himself to the family. Because the husband would not express any opinions to the wife, she gradually began to work hard alone in maintaining the family.

\subsubsection{Unintelligible Behavior}

After the marriage, the wives began noticing that their husbands were developing strange behavior and began failing to meet their expectations. The wives became perplexed because they could not understand their husbands' intentions. All the wives experienced some kind of unintelligible behaviors on the part of the husband.

"After we got married, I felt a sense of incompatibility between us. He did not take proper account of my situation or he could not adopt a proper attitude in important situations." (D)

\subsubsection{Self-Righteous Husband}

One wife reported that her husband did not change his opinion and did not listen to her opinion. The husband began getting angry with his wife over small 
things.

"My friends said to me, 'Aren't you tired of your husband's anger?' At times, I felt a little crazy, but I thought it wasn't that bad.” (G)

\subsection{3. "Husband Who Fails to Cooperate"}

One wife told the following story. The husband did not speak, and so the wife could not decide on important problems with her husband. The husband said he would go along with what she said, and so the wife had to decide everything.

"I express my opinion, but my husband doesn't say anything. My husband says it's OK. Other people don't understand my complaints. They think it must be wonderful if your husband does what you want him to do." $(\mathrm{H})$

\subsection{Struggle with a Sense of Loneliness}

This core category covers how the wife was suffering from discomfort and not being connected to her husband, leading to a struggle with a sense of loneliness. The categories, concepts, and definitions appear in Table 4. There are six categories: filled with a sense of loneliness, repressed emotion, spiral of self-doubt, anger and anxiety, corresponding ingenuity to husband, and resignation. The wives were struck with feelings of loneliness and having to cover their emotions. When that happened repeatedly, the wives began losing confidence in themselves; their anger and anxiety rose, and they began to give up on their husbands. The wives were unable to get out of this negative spiral. This negative process could sometimes last for a considerable time.

\subsubsection{Filled with a Sense of Loneliness}

Even though the husband and wife lived together, the wife felt as if there was a glass partition between them and she could not get her feelings across. The wife has a conflict in that the husband does not say to her what he wants to say. Even if the wife is in trouble, her husband will not cooperate.

"It was as if I were living alone in the house." (A)

\subsubsection{Repressed Emotion}

The wife killed her emotions, ignored painful truths, and made sacrifices. Thus, she was hiding her emotions.

"It can't be helped. But it's painful. How can my husband say something like a demon? He really doesn't understand my pain. I feel I will constantly have to endure this." (D)

\subsubsection{Spiral of Self-Doubt}

The wives believed that their husbands did not understand their feelings. The wives blamed themselves when the married life did not go well. The wives fell into a spiral of self-doubt.

"No matter how hard I try, he says nothing in return. If my husband thanked me when I praised him, I would be satisfied. But I get no satisfaction because my husband doesn't respond to my continuing praise. Nothing changes." (F) 
Table 4. Struggle with a sense of loneliness.

\begin{tabular}{|c|c|c|}
\hline Category & Concept & Definitions \\
\hline \multirow{3}{*}{$\begin{array}{l}\text { Filled with } \\
\text { a sense of } \\
\text { loneliness }\end{array}$} & Feeling of a glass partition & Even though the wife and husband live together, they feel like they are separated by glass \\
\hline & Emotionally distant & $\begin{array}{l}\text { The wife feels loneliness and conflict because of the things she wants to say are not } \\
\text { conveyed }\end{array}$ \\
\hline & Serious holdout & Even if the wife is in trouble, her husband will not cooperate with her \\
\hline \multirow{3}{*}{$\begin{array}{l}\text { Repressed } \\
\text { emotion }\end{array}$} & Kill emotions & $\begin{array}{l}\text { When the wife does not agree with her husband in her daily life, she endures and adapts } \\
\text { to her husband }\end{array}$ \\
\hline & Ignore the painful truth & $\begin{array}{l}\text { Even if there is something difficult about incompatibility with the husband, the wife } \\
\text { endures it alone }\end{array}$ \\
\hline & Sacrifices her life & The wife will sacrifice herself to keep her family and work hard to the limit \\
\hline \multirow{2}{*}{$\begin{array}{l}\text { Spiral of } \\
\text { self-doubt }\end{array}$} & $\begin{array}{l}\text { Impossible for husband to } \\
\text { understand her feelings }\end{array}$ & $\begin{array}{l}\text { The wife gives up on her husband's intention to get to know her feelings and stops trying } \\
\text { to make herself understood }\end{array}$ \\
\hline & Blaming herself & The wife blames herself because her family does not function well \\
\hline \multirow{3}{*}{$\begin{array}{l}\text { Anger and } \\
\text { anxiety }\end{array}$} & $\begin{array}{l}\text { Misunderstanding that the } \\
\text { husband's behavior is malicious }\end{array}$ & The wife misunderstands that her husband is being malicious because of his bad behavior \\
\hline & No cooperation for the family & $\begin{array}{l}\text { The husband cannot do any housework, and so the wife does not let him do the } \\
\text { housework }\end{array}$ \\
\hline & $\begin{array}{l}\text { Anxiety about responding } \\
\text { to children }\end{array}$ & $\begin{array}{l}\text { The wife feels uneasy about how her the husband's contact with his children is not like } \\
\text { a father's }\end{array}$ \\
\hline \multirow{5}{*}{$\begin{array}{l}\text { Corresponding } \\
\text { ingenuity to } \\
\text { husband }\end{array}$} & $\begin{array}{l}\text { Exploring ways to convey } \\
\text { her thoughts }\end{array}$ & $\begin{array}{l}\text { Because her opinion is not quite transmitted to the husband, the wife explores other ways } \\
\text { to convey her feelings }\end{array}$ \\
\hline & $\begin{array}{l}\text { Explaining using concrete } \\
\text { examples or logic }\end{array}$ & $\begin{array}{l}\text { The wife devises ways to convey her meaning to her husband using concrete examples } \\
\text { and logic }\end{array}$ \\
\hline & Writing on paper and telling & When spoken words do not convey well, the wife write them down on paper to tell him \\
\hline & $\begin{array}{l}\text { Asks her husband what } \\
\text { he can do }\end{array}$ & When the wife asks her husband to do something, she asks that he does jobs one at a time \\
\hline & $\begin{array}{l}\text { Respects the husband's } \\
\text { persistence }\end{array}$ & $\begin{array}{l}\text { The wife will try to respect her husband as much as she can if he is committed to what } \\
\text { he cares about }\end{array}$ \\
\hline \multirow{3}{*}{ Giving in } & Living at her own pace & $\begin{array}{l}\text { The wife is exhausted if she is with her husband, so she tries to maintain he own pace } \\
\text { for life }\end{array}$ \\
\hline & $\begin{array}{l}\text { Having no expectations } \\
\text { of her husband }\end{array}$ & The wife does not have excessive expectations of her husband so as to remain calm \\
\hline & $\begin{array}{l}\text { Thinking that is how a } \\
\text { man behaves }\end{array}$ & $\begin{array}{l}\text { Because the husband and wife are different, and the wife feels uncomfortable, } \\
\text { she thinks that all men are like that }\end{array}$ \\
\hline
\end{tabular}

"After I got married, I endured it for a long time. But it really got hard, and I began to blame myself. I lost my self-confidence." $(\mathrm{H})$

\subsubsection{Anger and Anxiety}

The wives had both anger and anxiety with respect to their husbands. From the wife's perspective, the husband did not have a cooperative relationship with his family, did not react properly to their child, and seemed to have some malicious intent. 
"My husband easily hurts people emotionally. Many times, I got angry and felt like hitting him." (I)

\subsubsection{Corresponding Ingenuity to Husband}

The wives began devising such ways as finding ways to express my thoughts, expressing myself in concrete or logical ways, writing things down on paper and telling him, asking my husband what he can do, and respecting my husband's persistence.

"He will do as I ask. So I will get him to do what I want. I am in charge of him, like a mother." (F)

"I feel like I've been exploring ways how to work with this person." (E)

\subsubsection{Giving in}

Some wives tried to give in to their husbands, living at his pace, not having any expectation of the husband, and accepting him as he was.

"I chose an amusing guy to get married to. I do not want what I cannot hope for." (F)

\subsection{Social Exclusion}

This core category covered increased social exclusion. The categories, concepts, and definitions appear in Table 5. There are two categories: "people do not understand me" and "being blamed for not living up to the wife's role". Through experiencing "people do not understand me" and "being blamed for not living up to the wife's role", the wife lost her whereabouts, role, and connection with others.

\subsubsection{People Do Not Understand Me}

Many wives said that they did not want to appear as if they were boasting to other people about their relationship with their husband, and so they tended to talk about things that were difficult for other people to understand. The wives said relatives, counselors, and friends could not properly understand them. The wives said that it was difficult living with such a lack of understanding.

"No one understands me well. I blame myself for being bad." (N)

"I had no feeling that the counselor understood me." $(\mathrm{H})$

\subsubsection{Being Blamed for Not Living up to the Wife's Role}

The wives were suffering because they felt themselves to be responsible, being blamed for not playing the proper role of the wife, and being blamed for their selfishness.

"I was told that 'the reason why your husband can't talk to you is that you want too much. You're selfish. You talk a lot.' None of my close friends, seniors, parents, or anyone understands me." (M)

\subsection{Social Inclusion}

This core category covered decreased social inclusion. The categories, concepts, 
Table 5. Social exclusion and social inclusion.

\begin{tabular}{|c|c|c|}
\hline Category & Concept & Definitions \\
\hline \multicolumn{3}{|c|}{ Core Category: Social exclusion } \\
\hline & $\begin{array}{l}\text { It is difficult for other people } \\
\text { to understand }\end{array}$ & $\begin{array}{l}\text { The state of the husband in the family is not understood and the wife seems to be } \\
\text { exaggerating }\end{array}$ \\
\hline \multirow[t]{4}{*}{$\begin{array}{l}\text { People do not } \\
\text { understand me }\end{array}$} & Her relatives do not understand & Relatives believe the family is not functioning because the wife's efforts are insufficient \\
\hline & Counselor does not understand & $\begin{array}{l}\text { Even if the wife consulted a counselor, the counselor may not understand her } \\
\text { husband's condition and her circumstances }\end{array}$ \\
\hline & Her friends do not understand & $\begin{array}{l}\text { Even if the wife talks to friends, they do not understand her husband and they } \\
\text { cannot understand her real point }\end{array}$ \\
\hline & Own responsibility & It is the wife's responsibility to suffer because she chose the husband \\
\hline \multirow{2}{*}{$\begin{array}{l}\text { Being blamed for } \\
\text { not living up to } \\
\text { the wife's role }\end{array}$} & $\begin{array}{l}\text { Blame for the wife who does } \\
\text { not play the wife's role }\end{array}$ & The wife is not playing her role so she is blamed for her family not doing well \\
\hline & Blamed as selfish & $\begin{array}{l}\text { The wife feels a sense of incompatibility with her husband because she is expecting } \\
\text { too much; she blames herself for being selfish }\end{array}$ \\
\hline \multicolumn{3}{|c|}{ Core Category: Social inclusion } \\
\hline \multirow{3}{*}{$\begin{array}{l}\text { Finding peace } \\
\text { of mind }\end{array}$} & Being devoted to parenting & Putting full effort into child rearing, not thinking only about the husband \\
\hline & Being devoted to social activities & Turning attention to social activities, not thinking only about the husband \\
\hline & Studying counseling & Learning counseling for self-healing \\
\hline \multirow{2}{*}{$\begin{array}{l}\text { Being saved by } \\
\text { empathy from } \\
\text { other people }\end{array}$} & $\begin{array}{l}\text { Saved by friends who } \\
\text { understand the situation }\end{array}$ & The wife feels saved by talking to someone who sympathizes with her closely \\
\hline & $\begin{array}{l}\text { Saved by experts who } \\
\text { understand the situation }\end{array}$ & The wife feels saved by an expert who recognizes and accepts her \\
\hline
\end{tabular}

and definitions appear in Table 5. There are two categories: finding peace of mind and being saved by empathy from other people. The wives reported having received support from other people. In their struggle with their sense of loneliness, the wives received good help from other individuals. Decreasing that sense of loneliness was most important to them.

\subsubsection{Finding Peace of Mind}

The wives found peace of mind through parenting and social activities as well as by studying counseling and folk remedies.

"The time I spent raising my child gave me power." (D)

\subsubsection{Being Saved by Empathy from Other People}

Some wives said they were saved by friends and experts who understood their situation.

"Thankfully, there's a mother who helps me in case of trouble. She's saved me quite a lot." (C) 


\subsection{Confronted with Life-Threatening Crisis}

This core category covered being confronted with a life-threatening crisis. The categories, concepts, and definitions appear in Table 6. There are three categories: physical difficulty, mental difficulty, and social difficulty. The process of struggle with a sense of loneliness having continued, the wives were finally driven to extreme situations by their husband's behavior. One of the wives who experienced this situation later managed to settle down; another one got divorced.

\subsubsection{Physical Difficulty}

The physical condition of the wives reached extremes as a result of the husbands' behavior.

"I suddenly became deaf, and my blood pressure shot to 200. I was told I had to stay in hospital, but I was ignored when I said that to my husband." (D)

\subsubsection{Mental Difficulty}

The mental condition of the wives also reached extremes owing to the husbands' behavior.

"My husband suddenly lost control. I got afraid and began hyperventilating." (G)

\subsubsection{Social Difficulty}

The wives had to endure social difficulties owing to their husbands' violence and lack of income.

"I was unable to make use of child care because he had no income. The domestic violence that is the result of our economic situation is awful." (B)

\section{Discussion}

In this study, we aimed to clarify the subjective experiences of wives of husbands with ASD from marriage to marital crisis. We conducted semi-structured interviews with 15 wives of husbands with ASD and analyzed the results using M-GTA. We extracted 53 concepts, 19 categories, and six core categories: attraction to the husband, discomfort with the husband, struggle with a sense of loneliness, social exclusion, social inclusion, and confrontation with a life-threatening

Table 6. Confronted with life-threatening crisis.

\begin{tabular}{lll}
\hline Category & \multicolumn{1}{c}{ Concept } & \multicolumn{1}{c}{ Definitions } \\
\hline $\begin{array}{l}\text { Physical } \\
\text { difficulty }\end{array}$ & $\begin{array}{l}\text { Reach a } \\
\text { physical limit }\end{array}$ & $\begin{array}{l}\text { Symptoms such as physical symptoms, chronic fatigue and } \\
\text { collapse that require hospitalization or surgery appear }\end{array}$ \\
$\begin{array}{l}\text { Mental } \\
\text { difficulty }\end{array}$ & $\begin{array}{l}\text { Reach a } \\
\text { mental limit }\end{array}$ & Mental illness such as depression that needs treatment occurs \\
$\begin{array}{l}\text { Economic } \\
\text { difficulty }\end{array}$ & $\begin{array}{l}\text { Eusband's } \\
\text { violence }\end{array}$ & $\begin{array}{l}\text { Physical, mental and sexual violence against the wife and } \\
\text { children by her husband }\end{array}$ \\
\hline
\end{tabular}


crisis. We analyzed the relationship between these six core categories and summarized the process from pre-marriage to marital crisis as follows. First, the wives felt attraction toward their husband before marriage, then they married their husband while unaware that their husband had ASD. Second, the wives began to feel discomfort toward their husband in their married life. Third, the wives started to struggle with a sense of loneliness through repeated feelings of discomfort on a daily basis. During that process, the wives were affected by social exclusion or social inclusion. Finally, the wives' prolonged struggle with their sense of loneliness led to their confrontation with a life-threatening crisis.

\subsection{Why Has the Married Life of ASD People Been Overlooked So Far?}

Traditionally, among clinicians, it has been recognized that ASD that does not occur in early childhood is not severe. Some clinicians believed that ASD individuals who got married experienced no social difficulties. Therefore, ASD individuals who get married life have not been studied (Engström, Ekström, \& Emilsson, 2003). It has been thought that ASD individuals rarely get married (Seltzer, Shattuck, Abbeduto, \& Greenberg, 2004).

The following points may be considered as the background to the oversight with respect to the wife's difficulties. The first point is that the characteristics of ASD are difficult to recognize in social situations; thus, the wife's sense of discomfort is less socially visible. That is because ASD is defined as persistent deficits in social communication and interactions (American Psychiatric Association, 2013). However, those aspects may be difficult to recognize in society. Because social communication is a phenomenon caused through people's interactions, it is not always clear when there is a sense of discomfort; such discomfort is felt by the wife of an ASD husband.

Furthermore, the characteristics of ASD are said to be on a continuum. Thus, because the boundary between "normal" and "disability" is ambiguous, that between "normal" and "sense of discomfort" felt by the wife is also likely to be ambiguous. From the above, it seems that the discomfort to the wife of an ASD husband has been misunderstood as being a normal occurrence in the lives of a couple; that makes it difficult to recognize from the perspective of society.

The second point is that it is difficult for society to understand such a marriage: there is a tendency to regard marriage as a matter of the married couple and their own responsibility. Accordingly, the wife tries not to reveal family problems to society because of a tacit understanding that the wife is responsible for her choice of marriage partner. In the present study, it was evident that the wives were charmed by their husbands and married them for love. However, that attraction turned into discomfort. That is covered in the fatal attraction theory (Felmlee, 1995), whereby the attraction that is a factor in the initial relationship between partners turns into disillusionment, which tears them apart. That phenomenon can happen to any couple. However, when the characteristics of ASD 
are regarded as attractive, the wife gradually becomes unable to compromise and her discomfort becomes greater. This phenomenon is socially difficult to understand unless other people have a close relationship with the couple in question. For these reasons, the wife's discomfort is difficult for society to understand.

\subsection{Loneliness and Social Exclusion Peculiar to the Wife of an ASD Husband}

In the process from marriage to marital crisis, the experiences unique to wives of ASD husbands were loneliness and social exclusion. The feeling of loneliness by the wives was deepened by losing connection with people, their whereabouts, and roles. The wives experienced a sense of social exclusion while pursuing their lives with their husbands. There are two reasons for the wives of ASD husbands wife falling into loneliness. The first derives from the couple's relationship. The wife repeatedly experiences "feeling like there is a glass partition between us," "emotionally distant," and having a "serious holdout" with her husband. We believed this to have been caused by the characteristics of her ASD husband. Commitment is believed to be important for maintaining intimate relationships (Le, Dove, Agnew, Korn, \& Mutso, 2010). The wife's repeated negative experience weakens her commitment, which makes their relationship increasingly difficult to maintain. The wife wants commitment, but her husband finds difficult owing to the characteristics of ASD. The wife feels increasingly isolated as this experience is repeated. The second reason comes from the relationship between the wife and people other than her husband. The wife talks to others who understand the relationship with her husband, but she repeatedly finds they cannot easily understand her. The reason other people cannot do so is that the characteristics of ASD are difficult to recognize from the outside. It has been pointed out that loneliness is an unpleasant experience that occurs when a person's network of social relations is deficient (Perlman \& Peplau, 1981). The wife feels lonely as a result of this unrecognized experience.

There are two reasons for the wives of ASD husband falling into social exclusion. The first is, as noted, that the characteristics of ASD are difficult to recognize from the outside. Therefore, the problems of the wives are hard to see, and it is difficult to obtain understanding from other people. The wife feels discomfort with her husband, is socially hard to recognize; she loses connection with people as experiences with her husband continue, and she cannot be properly understood even when talking to a person who is close to her. So the wife talks about her own feelings, the other person does not understand her, and the wife starts restricting her behavior; sometimes, she may lose her sense of place other than at home. The second point is that normative consciousness, such as division of sexual roles generally understood by modern families and strong emotional ties among family members, strengthens ASD characteristics. A marriage is often difficult to understand from the outside. The wife has various difficulties in her marriage with her ASD husband; it is possible that she tries to adapt excessively 
because of her ideals concerning the family and her own role in that. In addition, since her family is far from ideal, she may feel inadequate over her inability to fulfill her role.

By gradually losing her whereabouts, role, and connection with others, we consider that the wife who is struggling with loneliness became easier to fall into a crisis. In a previous study, the absence of whereabouts, role, and connection with others was found to be due to social exclusion (Emiko, 1989). However, in the present study, the wives also felt that they were socially excluded. Conversely, social inclusion creates whereabouts, role, and connection with other people. Social inclusion was a factor that helped stabilize married life for the wives with ASD husbands. However, even if they achieved stability at one time, the wives' repeated discomfort and social exclusion as a result of her husband are sufficient influence to cause a sense of loneliness and lead to a crisis.

\subsection{Daily Repeated Small Discomfort Leading to Life-Threatening Crisis}

Traditional family stress theory (Hill, 1958) focuses only on the family reaction after a life event posed a threat to the family. The results of the present study revealed that the wives of ASD husbands experienced a crisis that threatened their lives in married life through a repeated small sense of discomfort as a result of their husbands.

In married life, a feeling of repeated incongruity is the result of daily stress. One study found that the associations between external stress and relationship functioning are stronger for daily problems than for critical life events (Bodenmann, Ledermann, \& Bradbury, 2007). Even though each event may be small in itself, daily stress can have a great influence on wives. In this study, repeated discomfort occurred with everyday life with the ASD husband. In response, the wife had to change her life and tried to cope with that alone, which led to a deepening feeling of loneliness. Having a lack of understanding among other people about her feeling of discomfort and loneliness weakened the wife's connection with society and her sense of whereabouts; that created a structure of a greater disposition to loneliness. That sense occurred repeatedly as she tried to fight her loneliness. Even if one problem could be addressed, new problems arose; the wife gradually became unable to work hard alone and was in danger of a life-threatening crisis.

As well as family stress theory, it is necessary to think about daily stress after marriage. The marriage life crisis model for the wives of ASD husbands has something in common with the pattern for other wives. It is possible that such crises will change those wives' life. By understanding the process that leads to crisis, wives can differentiate between phenomena that can be changed by their own efforts and ones that can be changed only by trial and error. There is a possibility that it becomes easy to live by this. Understanding why a situation leads to a crisis makes it easier for different prospects to develop and possibly expand 
future options.

\subsection{Study Limitations}

This study has two limitations. First, the viewpoints of ASD individuals were not reflected. Marriage involves two people, but this study examined the subjective experiences of the wife. Second, our selection of wives with a great variety of experiences may not have been ideal sampling. The wives we targeted were people who could talk about their situation. There are some wives who cannot talk to anyone. Their situation is likely to be more serious.

\subsection{Practical Implication}

The findings of this study indicate that understanding and support are substantially important not only for ASD husbands but also for the wives of ASD husbands. That is, experiences of misunderstanding or a lack of understanding by doctors, nurses, counselors and other professionals can lead to social exclusion or the feeling of loneliness. Conversely, understanding and empathy from others close to these wives may enable social inclusion or the ability to maintain emotional balance under stressful circumstances. Therefore, to alleviate any marital crisis between ASD husbands and their wives, it is important to promote the understanding of professionals and the public.

\section{References}

Alexander-Passe, N. (2015). The Experience of Being Married to a Dyslexic Adult. Journal of Psychology \& Psychotherapy, 5, 2161-0487.

American Psychiatric Association (2013). Diagnostic and Statistical Manual of Mental Disorders $\left(D S M-5^{\oplus}\right)$. Washington, DC: American Psychiatric Pub.

Aston, M. (2003). Aspergers in Love: Couple Relationships and Family Affairs. London and New York: Jessica Kingsley Publishers.

Bodenmann, G., Ledermann, T., \& Bradbury, T. N. (2007). Stress, Sex, and Satisfaction in Marriage. Personal Relationships, 14, 551-569. https://doi.org/10.1111/j.1475-6811.2007.00171.x

Byers, E. S., Nichols, S., \& Voyer, S. D. (2013). Challenging Stereotypes: Sexual Functioning of Single Adults with High Functioning Autism Spectrum Disorder. Journal of Autism and Developmental Disorders, 43, 2617-2627. https://doi.org/10.1007/s10803-013-1813-Z

Emiko, O. (1989). Kindaikazoku to feminizumu (The Modern Family and Feminism). Tokyo: Keisoushobo.

Engström, I., Ekström, L., \& Emilsson, B. (2003). Psychosocial Functioning in a Group of Swedish Adults with Asperger Syndrome or High-Functioning Autism. Autism, 7, 99-110.

Felmlee, D. H. (1995). Fatal Attractions: Affection and Disaffection in Intimate Relationships. Journal of Social and Personal Relationships, 12, 295-311. https://doi.org/10.1177/0265407595122009

Glaser, B. G., \& Strauss, A. L. (1967). The Discovery of Grounded Theory: Strategies for Qualitative Research. Chicago, IL: Aldine. 
Hellemans, H., Colson, K., Verbraeken, C., Vermeiren, R., \& Deboutte, D. (2007). Sexual Behavior in High-Functioning Male Adolescents and Young Adults with Autism Spectrum Disorder. Journal of Autism and Developmental Disorders, 37, 260-269. https://doi.org/10.1007/s10803-006-0159-1

Hill, R. (1958). Generic Features of Families under Stress. Social Casework, 39, 139-150

Howlin, P., Mawhood, L., \& Rutter, M. (2000). Autism and Developmental Receptive Language Disorder-A Follow-Up Comparison in Early Adult Life. II: Social, Behavioural, and Psychiatric Outcomes. Journal of Child Psychology and Psychiatry, 41, 561-578. https://doi.org/10.1111/1469-7610.00643

Kanroji, J. (2012). A Study of the Relationship of the Married Couples with Autism Spectrum Disorders: The Communication of Married Couple and the Marital Satisfaction. Annual Bulletin of Clinical Center for Developmental Disorders, Shirayuri College, 15, 62-71.

Kinoshita, Y. (2003). M-GTA Modified Grounded Theory Approach-Grounded Theory Approach: Shitutekikenkyu he no sasoi. Tokyo: Kabushiki-gaishaKobunsha.

Lau, W., \& Peterson, C. C. (2011). Adults and Children with Asperger Syndrome: Exploring Adult Attachment Style, Marital Satisfaction and Satisfaction with Parenthood. Research in Autism Spectrum Disorders, 5, 392-399. https://doi.org/10.1016/j.rasd.2010.06.001

Lavee, Y. (2013). Stress Processes in Families and Couples. In Handbook of Marriage and the Family (pp. 159-176). Berlin: Springer.

https://doi.org/10.1007/978-1-4614-3987-5_8

Le, B., Dove, N. L., Agnew, C. R., Korn, M. S., \& Mutso, A. A. (2010). Predicting Nonmarital Romantic Relationship Dissolution: A Meta-Analytic Synthesis. Personal Relationships, 17, 377-390. https://doi.org/10.1111/j.1475-6811.2010.01285.x

Orsmond, G. I., Krauss, M. W., \& Seltzer, M. M. (2004). Peer Relationships and Social and Recreational Activities among Adolescents and Adults with Autism. Journal of Autism and Developmental Disorders, 34, 245-256.

https://doi.org/10.1023/B:JADD.0000029547.96610.df

Perlman, D., \& Peplau, L. A. (1981). Toward a Social Psychology of Loneliness. Personal Relationships, 3, 31-56.

Renty, J., \& Roeyers, H. (2007). Individual and Marital Adaptation in Men with Autism Spectrum Disorder and Their Spouses: The Role of Social Support and Coping Strategies. Journal of Autism and Developmental Disorders, 37, 1247-1255. https://doi.org/10.1007/s10803-006-0268-x

Rusbult, C. E., \& Buunk, B. P. (1993). Commitment Processes in Close Relationships: An Interdependence Analysis. Journal of Social and Personal Relationships, 10, 175-204. https://doi.org/10.1177/026540759301000202

Seltzer, M. M., Shattuck, P., Abbeduto, L., \& Greenberg, J. S. (2004). Trajectory of Development in Adolescents and Adults with Autism. Mental Retardation and Developmental Disabilities Research Reviews, 10, 234-247. https://doi.org/10.1002/mrdd.20038

Strunz, S., Schermuck, C., Ballerstein, S., Ahlers, C. J., Dziobek, I., \& Roepke, S. (2017). Romantic Relationships and Relationship Satisfaction among Adults with Asperger Syndrome and High-Functioning Autism. Journal of Clinical Psychology, 73, 113-125. https://doi.org/10.1002/jclp.22319

Tani, M., Kanai, C., Ota, H., Yamada, T., Watanabe, H., Yokoi, H., \& Kato, N. (2012). Mental and Behavioral Symptoms of Person's with Asperger's Syndrome: Relationships with Social Isolation and Handicaps. Research in Autism Spectrum Disorders, 6, 907-912. https://doi.org/10.1016/j.rasd.2011.12.004 
Yukawa, Y., Ota, H., Kanai, C., Tani, M., Yamada, T., Hashimoto, R., \& Iwanami, A. (2013). Clinical and Psychosocial Characteristics in Adults with Pervasive Development Disorders: A Survey in Japan. International Journal on Disability and Human Development, 12, 25-29. https://doi.org/10.1515/ijdhd-2012-0121 